\title{
Genetic structure of the Asian Grass Frog, Fejevarya limnocharis (Amphibia: Anura: Dicroglossidae) of Peninsular Malaysia: a preliminary report
}

\author{
Amirah Hurzaid ${ }^{1 *}$, Ibrahim Jaafar ${ }^{1}$, Zalina Awang ${ }^{1}$ and Siti Azizah Mohd Nor ${ }^{2,3}$
}

\begin{abstract}
Background: Fejevarya limnocharis (Dicroglossidae) is found widespread in Peninsular Malaysia. We analyzed the mitochondrial DNA control region sequence data to evaluate the genetic variability and population structure of this species, based on 106 individuals from 14 populations in the west coast (northwest and central west) and two populations from the east coast of Peninsular Malaysia.

Results: Of 519, 13 variable sites (six parsimony informative sites) were observed, defining 14 unique haplotypes. We found very low levels of genetic variability, with three of the 16 populations exhibiting total absence of genetic variation. Both phylogenetic analyses based on NJ and MP methods failed to detect any geographic structuring between the east and west coast (northwest and central west combined) populations.

Conclusions: Consequently, it can be inferred that genetic structuring F. limnocharis populations in the Peninsular Malaysia was largely shaped by natural barriers. However, when this breaks down as between the central west and east peninsular regions, genetic differentiation is reduced. Further studies, with more efficient markers and larger populations, especially from the southern regions, are required to corroborate the findings.
\end{abstract}

Keywords: Fejevarya limnocharis; Peninsular Malaysia; mtDNA; D-loop

\section{Background}

The Asian Grass Frog, Fejevarya limnocharis, is a common and widespread amphibian in South Asia and Southeast Asia. Its distribution covers a number of islands in Indonesia, the Philippines, Phuket, and Singapore and is also found as far as the northern, central, southern, and southwestern China (including Taiwan, Hong Kong, and Macau), western Japan, western half of Honshu, Shikoku and Kyushu Districts, and Nansei Islands. Recently, this species was introduced into Tsushima and Iki (van Dijk et al. 2009). It has also been observed throughout a wide range of altitudes ( 2 to 2,000 $\mathrm{m}$ ) in China (Fei and Ye, 2001). In Malaysia, the species is ubiquitous in disturbed habitats associated with human activities including paddy

\footnotetext{
* Correspondence: amirahhurzaid@gmail.com

1 Biological Sciences Program, School of Distance Education, Universiti Sains Malaysia, Minden, Penang 11800, Malaysia

Full list of author information is available at the end of the article
}

fields, roadsides, lawns, agricultural fields, football fields, and lowland forests (Inger and Stuebing, 1997; Ibrahim, 2004; Norhayati et al. 2009). Being widely distributed, $F$. limnocharis is an ideal subject for population genetics and phylogeographic investigations and the mechanisms or forces most likely to have been involved in shaping their population pattern.

Maternally inherited mitochondrial DNA is an efficient genetic marker in genetic-differentiation studies, due to its higher mutation rate of base substitution compared to nuclear DNA (Qiongying et al. 2006). The control region or displacement loop (D-loop) gene is the only noncoding segment in vertebrate mtDNA (Faber and Stepien, 1998) and encompasses the sites of initiation for $\mathrm{H}$-strand replication and both $\mathrm{H}$ - and L-strand transcription (Sumida et al. 2000). The D-loop segment evolves much faster than the average mitochondrial gene (Brown, 1985), although it also has short sequence elements conserved among most 
vertebrates studied (Wolstenholme, 1992). Because of its ability for rapid change, the D-loop region is an ideal choice for addressing population-level genetic questions (Hoelzel et al. 1991).

The genetic variation of amphibians in Malaysia using mtDNA sequencing methods have been reported by Ramlah (2009) and Ramlah et al. (2010). Their studies mainly involved amphibian populations from Malaysian Borneo (Sabah and Sarawak) with limited samples from Peninsular Malaysia. However, they have provided a foundation for further studies in addressing population subdivision of the Malaysian amphibians. The objective herein was to determine the genetic variation in F. limnocharis populations from 16 different populations throughout Peninsular Malaysia, through DNA sequencing of D-loop of mtDNA.

\section{Methods}

\section{Sampling location and collection}

A total of 106 individuals of F. limnocharis representing 16 populations throughout Peninsular Malaysia were sampled during the period of 2010 to 2011. These populations were provisionally divided into three regions; northwest, central west, and east (Table 1). The northwest was defined as the region in west Peninsular Malaysia restricted by the Titiwangsa mountain range in the east and Bintang mountain range in the south. Populations to the south of the Bintang mountain range and west of the southernmost tip of the Titiwangsa mountain range were categorized as central west Peninsular, whereas those east of the Titiwangsa mountain range were classified as east Peninsular (Figure 1)
(Tan et al. 2012). Freshly captured specimens were immediately identified by referring to Berry (1975) and Norhayati et al. (2009). All specimens were injected with benzocaine solution into its dorsal lymph sacs to humanely kill them before dissection. Each liver tissue (approximately $10 \mathrm{mg}$ ) was preserved in $95 \%$ ethanol and stored at room temperature (approximately $25^{\circ} \mathrm{C}$ ) until use. This study has been approved by the USM Ethics Committee. All practical steps to ameliorate suffering by specimens were taken throughout this study. Voucher specimens were then deposited at the Herpetological Collections, Universiti Sains Malaysia for future reference.

\section{Molecular analysis}

DNA extraction was with a DNeasy Tissue Kit (QIAGEN, Venlo, Limburg, Netherlands) according to manufacturer's instructions. A segment of the D-loop mtDNA gene was amplified using a pair of primers - forward primer 327-L (5'-CTG TCC ATA TCA TGA CTA CTT G-3') and reverse primer $885-\mathrm{H}\left(5^{\prime}\right.$-GGT CTT AGC TTG TAG AGA GGT C-3') (Zhong et al. 2008). PCR was done in a Peltier thermal cycler (MJ Research Waltham, MA, USA), with the following profile: pre-denaturation at $94^{\circ} \mathrm{C}$ for $1 \mathrm{~min}$, 30 cycles of denaturation at $94^{\circ} \mathrm{C}$, annealing at $50^{\circ} \mathrm{C}$, and extension at $70^{\circ} \mathrm{C}$ for $1 \mathrm{~min}$ each, followed by final extension at $72^{\circ} \mathrm{C}$ for $5 \mathrm{~min}$. The PCR products were then purified using Wizard ${ }^{\oplus}$ SV Gel and a PCR Clean-Up System by Promega (Promega Madison, WI, USA) and sequenced on an ABI3730XL Genetic Analyzer (Applied Biosystems, Foster City, CA, USA).

Table 1 Region, sampling localities, locality numbers, site abbreviations (abbrev.), and coordinates (latitude and longitude)

\begin{tabular}{|c|c|c|c|c|c|}
\hline Region & Population & Locality number & Abbrev. & Latitude (N) & Longitude (E) \\
\hline \multirow[t]{11}{*}{ Northwest Peninsular } & Pulau Langkawi, Kedah & 1 & LKW & $6.31346^{\circ}$ & $99.77410^{\circ}$ \\
\hline & Jitra, Kedah & 2 & JIT & $6.26008^{\circ}$ & $100.41717^{\circ}$ \\
\hline & Lembah Bujang, Kedah & 3 & LBG & $5.73709^{\circ}$ & $100.41437^{\circ}$ \\
\hline & Sedim, Kedah & 4 & SED & $5.49962^{\circ}$ & $100.62954^{\circ}$ \\
\hline & Ulu Paip, Kedah & 5 & ULP & $5.39229^{\circ}$ & $100.66593^{\circ}$ \\
\hline & Sungai Burung, Penang & 6 & SBG & $5.33592^{\circ}$ & $100.22379^{\circ}$ \\
\hline & Sungai Acheh, Penang & 7 & SGA & $5.12341^{\circ}$ & $100.42055^{\circ}$ \\
\hline & Bukit Panchor, Penang & 8 & BPR & $5.15224^{\circ}$ & $100.53479^{\circ}$ \\
\hline & Kuala Kangsar, Perak & 9 & KK & $4.76851^{\circ}$ & $100.93929^{\circ}$ \\
\hline & Pusing, Perak & 10 & PUS & $4.49405^{\circ}$ & $101.01008^{\circ}$ \\
\hline & Langkap, Perak & 11 & LKP & $4.06534^{\circ}$ & $101.14691^{\circ}$ \\
\hline \multirow[t]{3}{*}{ Central west Peninsular } & Sabak Bernam, Selangor & 12 & SBK & $3.67576^{\circ}$ & $100.98998^{\circ}$ \\
\hline & Tanjong Karang, Selangor & 13 & TJG & $3.42258^{\circ}$ & $101.17671^{\circ}$ \\
\hline & Kepong, Kuala Lumpur & 14 & KEP & $3.23599^{\circ}$ & $101.63449^{\circ}$ \\
\hline \multirow[t]{2}{*}{ East Peninsular } & Kubang Kerian, Kelantan & 15 & $\mathrm{KBG}$ & $6.10020^{\circ}$ & $102.28502^{\circ}$ \\
\hline & Besut, Terengganu & 16 & BST & $5.61088^{\circ}$ & $102.51926^{\circ}$ \\
\hline
\end{tabular}




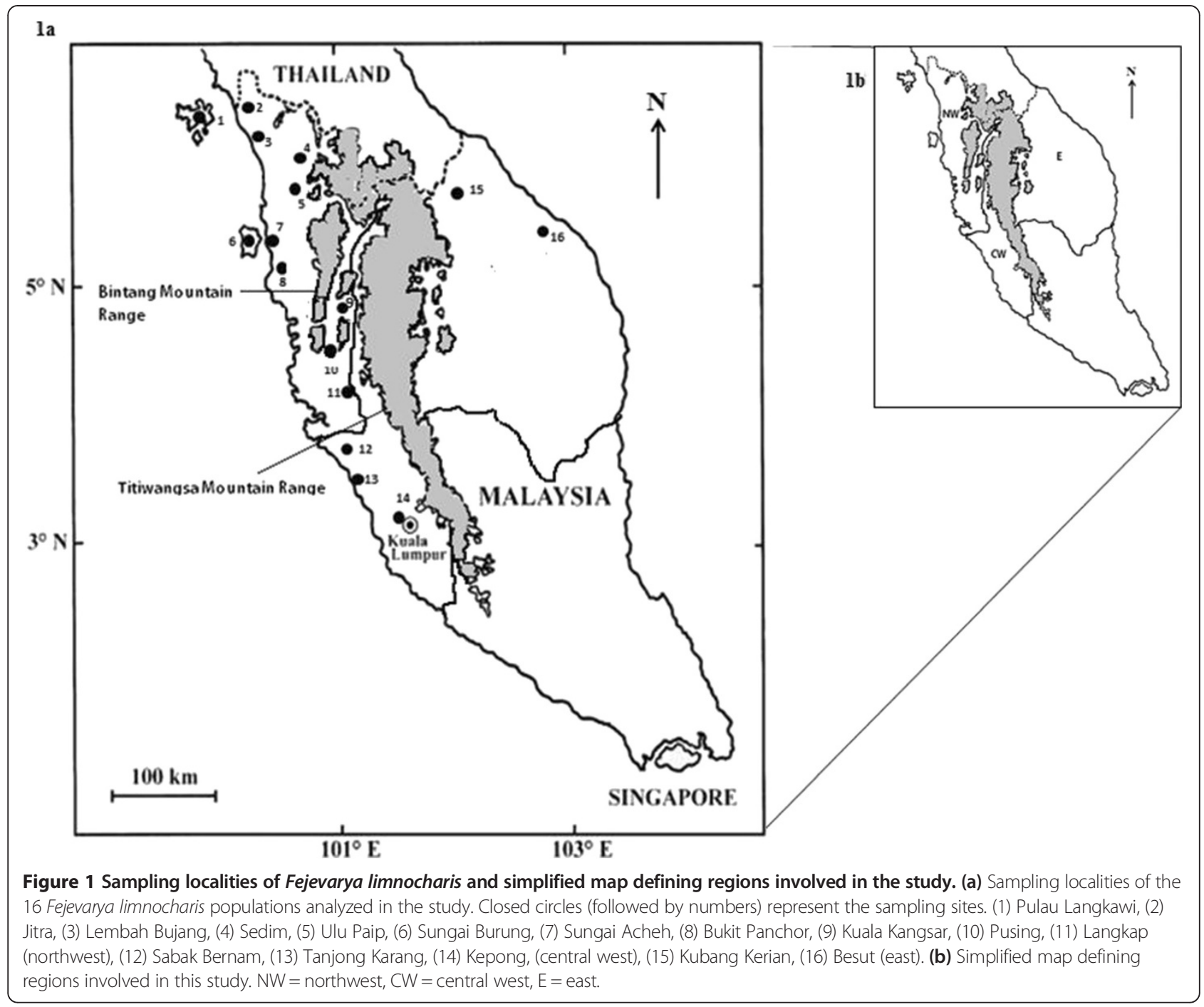

\section{Data analysis}

Sequences were edited using MEGA 6.0 (Tamura et al., 2013) and aligned with Clustal W 1.6, implemented in the same software. The aligned sequences were then referenced to the Basic Local Alignment Search Tool (BLAST; http://www.ncbi.nlm.nih.gov/blast) to confirm the identity of the samples, where possible. The aligned sequences were then exported to Collapse version 1.2 (Vigo, Spain) (Posada 2004) to compute the haplotype datasheet. Haplotype sequences were then generated using DNA Sequences Polymorphism (DnaSP) program version 5.10.01 (Librado and Rozas, 2009). Arlequin

Table 2 Number of samples ( $N$ ), nucleotide diversity, number of haplotypes, haplotype diversity, and number of polymorphic sites, data generated by ARLEQUIN version 3.0 software

\begin{tabular}{|c|c|c|c|c|c|c|c|c|c|c|c|c|c|c|c|c|}
\hline & \multicolumn{9}{|c|}{ Northwest } & \multicolumn{5}{|c|}{ Central west } & \multicolumn{2}{|l|}{ East } \\
\hline & LKW & JIT & LBG & SED & ULP & SBG & BPR & SGA & PUS & LKP & KK & SBK & TJG & KEP & KBG & BST \\
\hline & $N=4$ & $N=4$ & $N=3$ & $N=7$ & $N=3$ & $N=4$ & $N=8$ & $N=6$ & $N=7$ & $N=8$ & $N=5$ & $N=7$ & $N=16$ & $N=5$ & $N=6$ & $N=13$ \\
\hline Nucleotide diversity $(\pi)$ & 0.001 & 0.002 & 0.000 & 0.003 & 0.001 & 0.000 & 0.001 & 0.001 & 0.000 & 0.003 & 0.001 & 0.004 & 0.004 & 0.004 & 0.001 & 0.006 \\
\hline Number of haplotypes & 2 & 3 & 1 & 3 & 2 & 1 & 2 & 2 & 1 & 3 & 2 & 4 & 3 & 2 & 2 & 5 \\
\hline Haplotype diversity $(h)$ & 0.500 & 0.833 & 0.000 & 0.667 & 0.667 & 0.000 & 0.536 & 0.600 & 0.000 & 0.464 & 0.400 & 0.714 & 0.675 & 0.400 & 0.333 & 0.744 \\
\hline Number of polymorphic sites & 1 & 2 & 0 & 5 & 1 & 0 & 1 & 1 & 0 & 6 & 1 & 6 & 5 & 4 & 1 & 8 \\
\hline
\end{tabular}

LKW Langkawi, JIT Jitra, LBG Lembah Bujang, SED Sedim, ULP Ulu Paip, SBG Sungai Burung, BPR Bukit Panchor, SGA Sungai Acheh, PUS Pusing, LKP Langkap, KK Kuala Kangsar, SBK Sabak Bernam, TJG Tanjong Karang, KEP Kepong, KBG Kubang Kerian, BST Besut. 
version 3.0 (Excoffier et al. 2005) was used for calculating nucleotide and haplotype diversities and $\mathrm{F}_{\mathrm{ST}}$ values. Bonferroni correction was applied, with global significance level at 0.05 to correct for multiple comparisons. A bootstrap (10,000 replicates) neighbor-joining (NJ) and maximum parsimony (MP) tree was constructed based on the Kimura-2-parameter model (Kimura 1980) to depict haplotype relationships using the MEGA 6.0 software. A minimum-spanning network (MSN) connecting all haplotypes was generated using Network (Bandelt et al. 1999) program to illustrate this relationship.

\section{Results}

Final aligned sequences of 519 bp in the mtDNA D-loop gene were obtained. Fourteen unique haplotypes were identified from the 16 populations of 106 individuals. The sequences have been submitted to the GenBank (accession numbers KF051071 to KF051084). Low within population nucleotide diversity, $\pi(0.000$ to 0.006$)$ was observed in all populations while haplotype diversity, $h$, was in the range of very low to moderate in each locality ( $h=0.000$ to 0.833 ). Number of haplotypes and polymorphic sites per population ranged from 1 to 8 (Table 2). Trend of low intrapopulation variability was also supported by the genetic distances observed based on Kimura-2 parameter (Table 3).

The minimum spanning network relationships among all the haplotypes are presented in Figure 2. The two common haplotypes, namely Haplotype 1 and Haplotype 5 , were observed in almost equal frequency $(35 \%$ and $38 \%$, respectively). Haplotype 1 was common to all three regions although was missing in one population each in central west and east (Kepong and Kubang Kerian) while Haplotype 5 was observed in all central west and the eastern regions except a few populations namely from Sedim, Pusing, Langkap, and Kuala Kangsar (northwest). Eleven of the 14 haplotypes (except 1, 3, and 5) were unique to either the western or eastern regions.

Low genetic differentiation among populations in the northwest region was indicated by the low pairwise $F_{S T}$ (Table 3) values. Populations from central west and eastern regions were highly differentiated from the northwest populations with the exception of Sabak Bernam (central west), which showed low genetic differentiation with the northwest population. This was strongly supported by the NJ (data not shown) and MP phylogenetic trees, which divided the haplotypes into two major groups with high bootstrap values (100\%) (Figure 3).

\section{Discussion}

The present study has provided initial insights into the genetic distribution of F. limnocharis in Peninsular Malaysia. In general, mean nucleotide and haplotype diversities were low over all samples $(\pi=0.004 \pm 0.00005 ; h=0.471 \pm 0.27)$.
Grant and Bowen (1998) hypothesized that populations with low values of both parameters $(\pi \leq 0.5 \%, h<0.5)$ is a feature of recent population bottleneck or founder event by a single or a few mtDNA lineages. Farjallah et al. (2012), through Cytb gene analysis, reported that low levels of both nucleotide and haplotype diversities $(\pi=$ 0.002; $\mathrm{h}=0.7$ ) in the North African Green Frog Pelophylax saharicus in Tunisia may be due to a recent population expansion from a small founder population. Nevertheless, as a consequence of marker characteristics, an underestimation of the true levels of genetic variability is possible. Hence, other markers for population studies, such as microsatellites, should also be investigated.

Regional genetic differentiation among F. limnocharis populations were relatively high between the northwest with central west (excluding Sabak Bernam population) populations and each pairwise population comparison between the two regions showed significant genetic differentiation, the Bintang range being an effective divider between the two regions. However, remarkably high intra-regional gene flow was observed within the northwest region, perhaps a result of connectivity between populations of this region.

In contrast, the central west and east coast region showed unexpected genetic homogeneity. Some frog species use roads as activity corridors, including the Cane Toad, Bufo marinus (Seabrook and Dettmann, 1996), and Natterjack Toad, Bufo calamita (Stevens et al. 2006). Fejevarya limnocharis is generally abundant in human habitation and this may increase the opportunity for the frog to be transported accidentally or deliberately into new areas (Toda et al. 1997). Thus, it seems plausible that migration had occurred between the central west and east coast of Peninsular Malaysia via the East-West Highway and colonized new populations, thus reducing their genetic differentiation. This is in tandem with the high capability of dispersal possessed by this species.

It is not possible to compare the pattern of population structuring with other Malaysian amphibians as to date only limited molecular data (Ramlah et al. 2010) is available on the amphibians in Peninsular Malaysia. More intensive sampling on the investigated sites or sampling of increased number of sites particularly in the east coast and southern regions could confirm this.

\section{Conclusions}

Based on this preliminary analysis, it can be inferred that the genetic structuring of the Peninsular Malaysia F. limnocharis population was largely shaped by natural barriers. However, when this breaks down as between the central west and east Peninsular regions, genetic differentiation is reduced. Further studies, with more efficient markers and larger populations, especially from the southern regions, are required to corroborate the findings. 
Table 3 Pairwise $\mathrm{F}_{\mathrm{ST}}$ values (below diagonal) and mean pairwise genetic distance within (on diagonal) and between (above diagonal) the 16 populations of Fejevarya limnocharis

\begin{tabular}{|c|c|c|c|c|c|c|c|c|c|c|c|c|c|c|c|c|}
\hline \multicolumn{5}{|l|}{ Region } & \multicolumn{7}{|l|}{ Northwest } & \multicolumn{3}{|l|}{ Centralwest } & \multicolumn{2}{|l|}{ East } \\
\hline Population & LKW & JIT & LBG & SED & ULP & SBG & BPR & SGA & PUS & LKP & KK & SBK & TJG & KEP & KBG & BST \\
\hline LKW & 0.001 & 0.001 & 0.000 & 0.002 & 0.001 & 0.000 & 0.002 & 0.001 & 0.010 & 0.009 & 0.011 & 0.002 & 0.008 & 0.009 & 0.011 & 0.006 \\
\hline JIT & 0.000 & 0.002 & 0.001 & 0.002 & 0.001 & 0.001 & 0.002 & 0.001 & 0.009 & 0.008 & 0.009 & 0.003 & 0.007 & 0.007 & 0.009 & 0.006 \\
\hline LBG & -0.091 & -0.091 & 0.000 & $(0.002)$ & 0.001 & 0.000 & 0.001 & 0.001 & 0.010 & 0.009 & 0.010 & 0.002 & 0.007 & 0.008 & 0.010 & 0.006 \\
\hline SED & 0.051 & -0.144 & -0.033 & 0.003 & 0.002 & 0.002 & 0.002 & 0.002 & 0.008 & 0.007 & 0.008 & 0.003 & 0.007 & 0.007 & 0.008 & 0.006 \\
\hline ULP & $(0.403)$ & 0.102 & 0.415 & -0.023 & 0.001 & 0.001 & 0.001 & 0.001 & 0.009 & 0.008 & 0.009 & 0.002 & 0.007 & 0.008 & 0.009 & 0.006 \\
\hline SBG & 0.258 & -0.043 & 0.250 & -0.090 & -0.134 & 0.000 & 0.001 & 0.001 & 0.010 & 0.009 & 0.010 & 0.002 & 0.007 & 0.008 & 0.010 & 0.006 \\
\hline BPR & 0.000 & 0.000 & 0.000 & 0.034 & 0.461 & 0.314 & 0.001 & 0.001 & 0.009 & 0.008 & 0.009 & 0.003 & 0.007 & 0.007 & 0.009 & 0.006 \\
\hline SGA & 0.014 & -0.268 & 0.000 & -0.213 & -0.085 & -0.258 & 0.111 & 0.001 & 0.009 & 0.008 & 0.009 & 0.003 & 0.007 & 0.007 & 0.009 & 0.006 \\
\hline PUS & $(0.968)^{*}$ & $(0.924)^{*}$ & $(1.000)^{*}$ & $(0.786)$ & $(0.934)^{*}$ & $(0.939)^{*}$ & $(1.000)^{*}$ & $(0.964)$ & 0.000 & 0.001 & 0.000 & 0.008 & 0.003 & 0.002 & 0.000 & 0.005 \\
\hline LKP & $(0.754)$ & $(0.678)^{*}$ & $(0.754)$ & $(0.573)$ & $(0.748)^{*}$ & $(0.731)$ & $(0.776)$ & $(0.700)$ & -0.018 & 0.003 & 0.002 & 0.008 & 0.003 & 0.003 & 0.002 & 0.005 \\
\hline KK & (0.919) & $(0.859)^{*}$ & (0.949) & $(0.723)$ & $(0.894)^{*}$ & $(0.891)^{*}$ & $(0.956)$ & (0.899) & 0.073 & -0.004 & 0.001 & 0.009 & 0.003 & 0.002 & 0.001 & 0.005 \\
\hline SBK & -0.026 & -0.103 & -0.123 & -0.081 & $(0.170)$ & 0.063 & -0.055 & -0.127 & $(0.778)^{*}$ & $(0.577)$ & $(0.716)^{*}$ & 0.004 & 0.007 & 0.007 & 0.009 & 0.006 \\
\hline TJG & $(0.622)^{*}$ & $(0.551)^{*}$ & 0.610 & $(0.473)$ & $(0.643)^{*}$ & $(0.619)^{*}$ & $(0.630)$ & $(0.578)$ & $(0.199)$ & 0.034 & 0.163 & $(0.455)^{*}$ & 0.004 & 0.004 & 0.003 & 0.005 \\
\hline KEP & $(0.749)$ & 0.649 & $(0.754)^{*}$ & $(0.514)$ & $(0.734)$ & $(0.715)$ & $(0.786)$ & $(0.674)$ & 0.073 & -0.146 & 0.000 & $(0.530)$ & 0.045 & 0.003 & 0.002 & 0.005 \\
\hline KBG & $(0.927)$ & $(0.874)^{*}$ & $(0.954)$ & $(0.742)^{*}$ & $(0.901)^{*}$ & $(0.900)^{*}$ & $(0.960)^{*}$ & $(0.911)$ & 0.028 & -0.027 & 0.003 & $(0.736)^{*}$ & $(0.180)$ & 0.026 & 0.001 & 0.005 \\
\hline BST & $(0.288)$ & 0.178 & 0.244 & 0.118 & $(0.300)$ & $(0.264)$ & 0.287 & 0.181 & $(0.282)$ & 0.118 & 0.235 & 0.134 & 0.066 & 0.042 & 0.257 & 0.006 \\
\hline
\end{tabular}

Significant probabilities $(P<0.05)$ based on 1,000 permutations of haplotype frequencies among samples are indicated in parentheses.

*Significant population differentiation via exact test (after Bonferroni corrections), $P<0.05$.

LKW Langkawi, JIT Jitra, LBG Lembah Bujang, SED Sedim, ULP Ulu Paip, SBG Sungai Burung, BPR Bukit Panchor, SGA Sungai Acheh, PUS Pusing, LKP Langkap, KK Kuala Kangsar, SBK Sabak Bernam, TJG Tanjong Karang, KEP Kepong, KBG Kubang Kerian, BST Terengganu. 


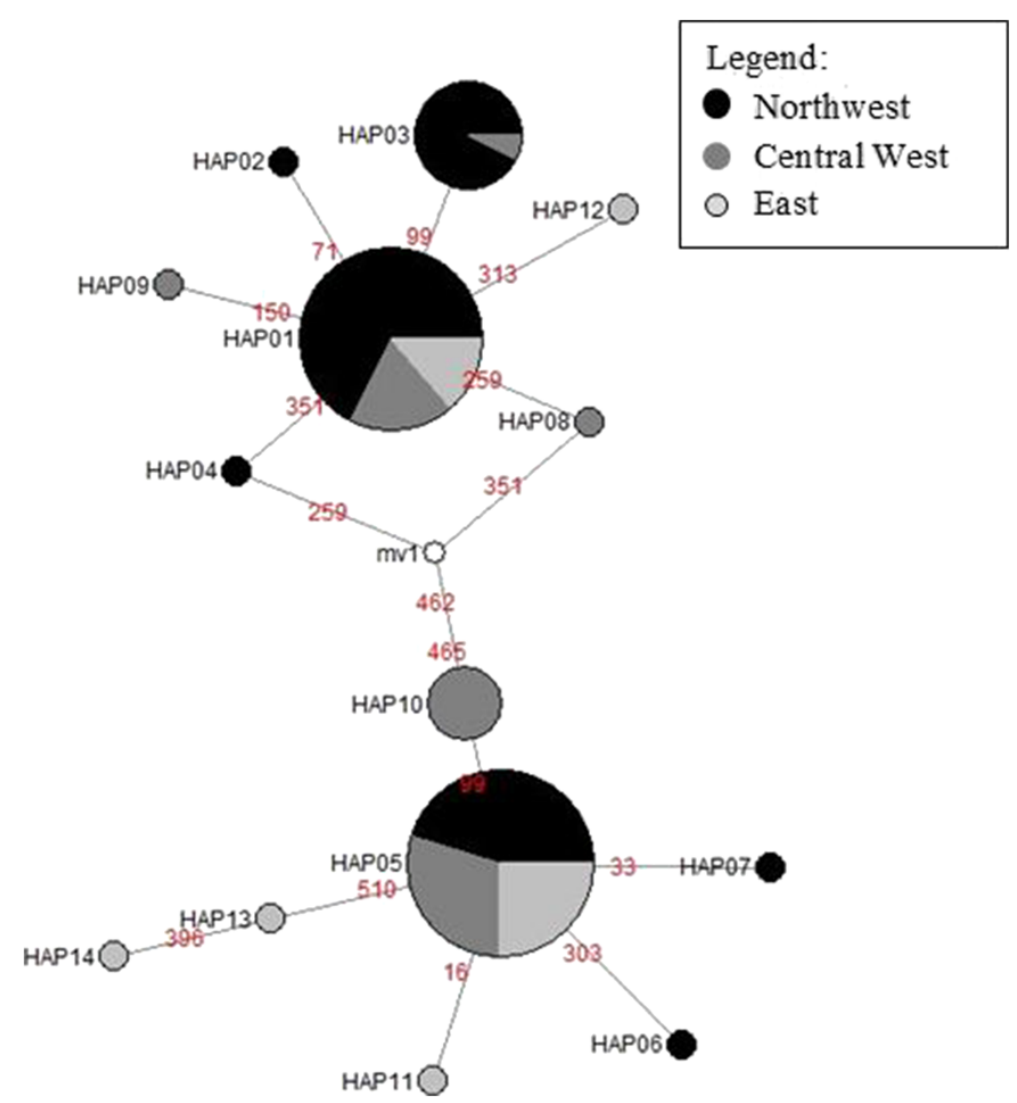

Figure 2 Minimum spanning network showing relationships among 14 haplotypes of mtDNA D-loop gene of $F$. limnocharis. Minimum spanning network showing relationships among 14 haplotypes of mtDNA D-loop gene of $F$. limnocharis, classified according to regions. The nucleotide mutation sites joining two haplotypes are showed in numbers. The size of each circle is an approximate indication of haplotype frequency [black circle found in northern region populations; dark gray circle found in northwest region populations; light gray circle found in east populations; open circle is the intermediate (mv)].

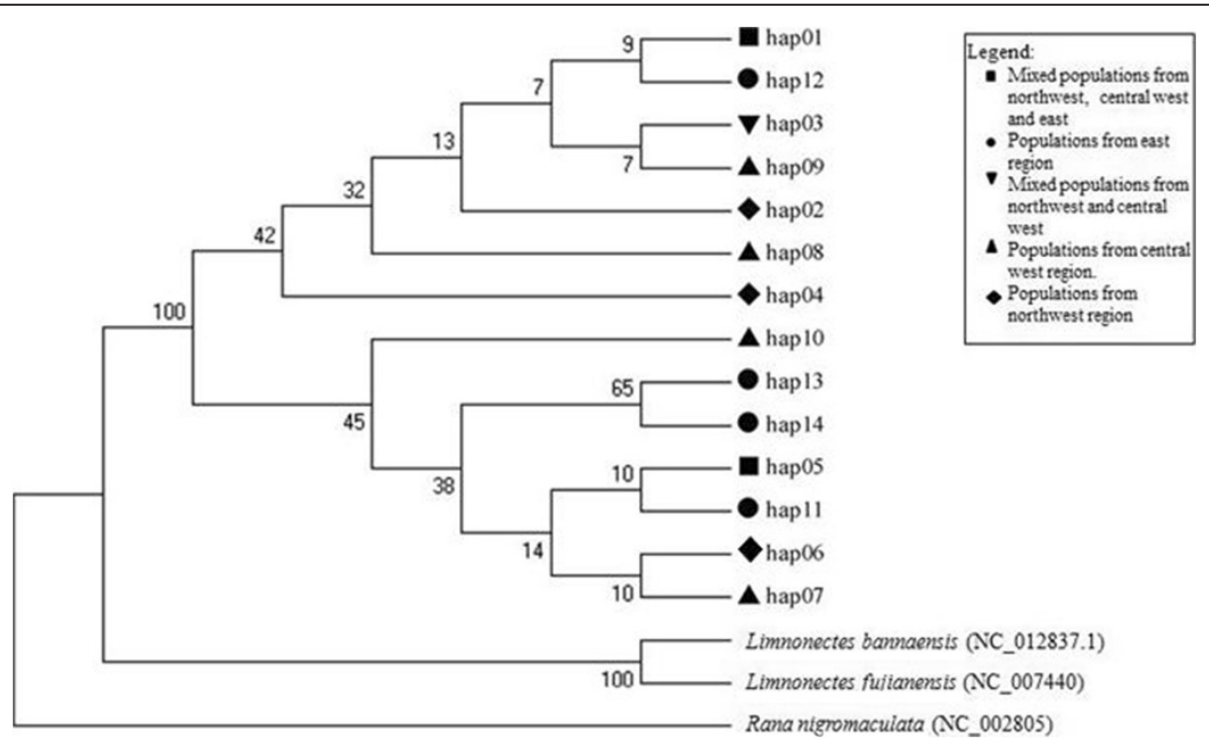

Figure 3 Maximum parsimony tree based on the Kimura-2-parameter distance model. Maximum parsimony tree based on the Kimura-2-parameter distance model showing the control region haplotype relationships among 16 populations of Fejevarya limnocharis. The numbers on branches indicate the bootstrap values based on 10, 000 replications. 


\section{Competing interests}

The authors declare that they have no competing interests.

\section{Authors' contributions}

The work presented here was carried out in collaboration among all authors. $\mathrm{AH}, \mathrm{IJ}$, and SAMN defined the research theme. $\mathrm{AH}$ carried out the molecular genetic studies, participated in the sequence alignment, and drafted the manuscript. AH, IJ, and ZA collected most of the samples in Peninsular Malaysia and wrote the paper. ZA participated in the sequence alignment. IJ participated in the final ID of the samples. SAMN conceived of the study and participated in its design and coordination and helped to draft the manuscript. All authors read and approved the final manuscript.

\section{Acknowledgements}

We wish to thank the staff of the School of Distance Education for excellent logistics and hospitality provided. We also wish to express our gratitude to our colleagues for their technical assistance. The research is supported by the Universiti Sains Malaysia Postgraduate Research Grant Scheme No. 5001/ PJJAUH/815034 awarded to the first author and the Universiti Sains Malaysia Research University Grant No. 1001/PJJAUH./815030 to the second author.

\section{Author details}

${ }^{1}$ Biological Sciences Program, School of Distance Education, Universiti Sains Malaysia, Minden, Penang 11800, Malaysia. ${ }^{2}$ School of Biological Sciences, Universiti Sains Malaysia, Minden, Penang 11800, Malaysia. ${ }^{3}$ Centre for Marine and Coastal Studies, Universiti Sains Malaysia, Minden, Penang 11800, Malaysia.

Received: 12 June 2014 Accepted: 14 November 2014 Published online: 17 December 2014

\section{References}

Bandelt HJ, Forster P, Röhl A (1999) Median-joining networks for inferring intraspecific phylogenies. Mol Biol Evol 16:37-48

Berry PY (1975) The amphibian fauna of Peninsular Malaysia. Tropical Press, Kuala Lumpur

Brown WM (1985) The mitochondrial genome of animals. Mol Evol Genet 95

Excoffier L, Laval G, Schneider S (2005) Arlequin ver. 3.0: an integrated software package for population genetics data analysis. Evol Bioinform Online 2:47-50

Faber JE, Stepien CA (1998) Tandemly repeated sequences in the mitochondrial DNA control region and phylogeography of the Pike-perches Stizostedion. Mol Phylogenet Evol 10(3):310-322

Farjallah S, Amor N, Merella P, Said K (2012) Pattern of genetic diversity of North African green frog Pelophylax saharicus (amphibia) in Tunisia. Pak J Bio Sci 44 (4):901-907

Fei L, Ye CY (2001) The colour handbook of amphibians of Sichuan. China Forestry Publishing House, Beijing

Grant WAS, Bowen BW (1998) Shallow population histories in deep evolutionary lineages of marine fishes: insights from sardines and anchovies and lessons for conservation. J Hered 89(5):415-426

Hoelzel AR, Hancock JM, Dover GA (1991) Evolution of the cetacean mitochondrial D-loop region. Mol Biol Evol 8(4):475-493

Ibrahim J (2004) Aspects of biology and ecology of two sympatric frog species in Malaysia. Yusran Publishing House, Sungai Petani

Inger RF, Stuebing RB (1997) A field guide to the frogs of Borneo. Natural History Publications, Kota Kinabalu

Kimura M (1980) A simple method for estimating evolutionary rates of base substitutions through comparative studies of nucleotide sequences. J Mol Evol 16(2):111-120

Librado P, Rozas J (2009) DnaSP v5: a software for comprehensive analysis of DNA polymorphism data. Bioinformatics 25(11):1451-1452

Norhayati A, Belabut DM, Chan KO (2009) Amphibians and reptiles of Peninsular Malaysia. http://amphibia.my/index.php. Accessed 22 December 2009

Posada D (2004) Collapse: describing haplotypes from sequence alignments. University of Vigo, Spain

Qiongying T, Huanzhang L, Mayden R, Bangxi X (2006) Comparison of evolutionary rates in the mitochondrial DNA cytochrome $b$ gene and control region and their implications for phylogeny of the Cobitoidea (Teleostei, Cypriniformes). Mol Phylogenet Evol 39:347-357
Ramlah Z (2009) Ecology and molecular phylogenetics of frogs from the genus Rana Linnaeus 1758 in Sarawak. Universiti Malaysia Sarawak, Sarawak, Dissertation

Ramlah Z, Shukor MN, Norhayati A, Md-Zain BM (2010) Genetic structure of Hylarana erythraea (Amphibia: Anura: Ranidae) from Malaysia. Zool Stud 49(5):688-702

Seabrook WA, Dettmann EB (1996) Roads as activity corridors for cane toads in Australia. J Wildl Manag 60:363-368

Stevens VM, Leboulengé É, Wesselingh RA, Baguette M (2006) Quantifying functional connectivity: experimental assessment of boundary permeability for the natterjack toad (Bufo calamita). Oecologia 150(1):161-171

Sumida M, Kaneda H, Kato Y, Kanamori Y, Yonekawa H, Nishioka M (2000) Sequence variation and structural conservation in the D-loop region and flanking genes of mitochondrial DNA from Japanese pond frogs. Genes Genet Sys 75(2):79-92

Tamura K, Stecher G, Peterson D, Filipski A, Kumar S (2013) MEGA6: molecular evolutionary genetics analysis version 6.0. Mol Biol Evol 30:2725-2729

Tan MP, Jamsari AFJ, Siti Azizah MN (2012) Phylogeographic pattern of the striped snakehead, Channa striata in Sundaland: ancient river connectivity, geographical and anthropogenic signatures. PloS One 7(12):1-11

Toda M, Nishida M, Matsui M, Wu GF, Ota H (1997) Allozyme variation among East Asian populations of the Indian rice frog, Rana limnocharis (Amphibia: Anura). Biochem Syst Ecol 25(2):143-159

van Dijk PP, Iskandar D, Inger R, Neng Lau MW, Ermi Z, Baorong G, Dutta S, Manamendra-Arachchi K, de Silva A, Bordoloi S, Kaneko Y, Matsui M, Sharif Khan M. (2009). Fejervarya limnocharis. In: IUCN 2014. IUCN Red List of Threatened Species. Version 2014.2. www.iucnredlist.org. Accessed 25 September 2014

Wolstenholme DR (1992) Animal mitochondrial DNA: structure and evolution. Int Rev Cytol 141:173-216

Zhong J, Liu ZQ, Wang YQ (2008) Phylogeography of the rice frog, Fejervarya multistriata (Anura: Ranidae), from China based on mtDNA D-loop sequences. Zool Sci 25(8):811-820

\section{doi:10.1186/s40555-014-0077-4}

Cite this article as: Hurzaid et al:: Genetic structure of the Asian Grass Frog, Fejevarya limnocharis (Amphibia: Anura: Dicroglossidae) of Peninsular Malaysia: a preliminary report. Zoological Studies 2014 53:77.

\section{Submit your manuscript to a SpringerOpen ${ }^{\circ}$ journal and benefit from:}

- Convenient online submission

Rigorous peer review

- Immediate publication on acceptance

- Open access: articles freely available online

- High visibility within the field

- Retaining the copyright to your article

Submit your next manuscript at springeropen.com 